\title{
Faktor demografi dan obstetrik dalam mempengaruhi kualitas hidup postpartum
}

\author{
Risky Puji Wulandari, ${ }^{1 *}$ Mufdlilah $^{2}$ \\ ${ }^{1}$ Program Magister Kebidanan, Fakultas Kesehatan, Universitas 'Aisyiyah Yogyakarta - \\ Indonesia, ${ }^{2}$ Fakultas Kesehatan, Universitas 'Aisyiyah Yogyakarta - Indonesia
}

\begin{abstract}
The postpartum period is one of the critical transition periods in women's lives, both physically and psychologically. The low quality of life for women, especially postpartum mothers, is caused by the postpartum period's needs in the form of physical, psychological, and social needs. Women who have an essential role, mature basis, and quality of life are important to measure postpartum care accuracy. The purpose of this study was to determine the factors that affect the quality of postnatal life in the work area of Mertoyudan I Health Center, Magelang Regency. This type of research is quantitative research with a cross-sectional research design. The sampling technique used accidental sampling. The number of samples in this study was 60 postpartum mothers. The research instrument was a questionnaire on demographic factors (age, education, residence status, occupation, stage), obstetric questionnaires (parity, type of baby present, history of pregnancy, history of abortion, desired pregnancy, and breastfeeding factors), and the Postpartum Quality of Life questionnaire. (PQOL). The study results with the results of the Chi-Square statistical test prove that there is an influence of demographic factors including age, education, and stage variables on the quality of life postpartum with p-value $0.003<0.05$, p-value $0.001<0.05$, and p-value $0.002<0.05$. Obstetric factors including parity, history of complications, history of abortion, desired pregnancy, and breastfeeding factors influence the quality of life postpartum with $p$-value $<0.050$, p-value $<003$, p-value $<0.040, p$-value $<0.000$, p-value value $<0.017$, and $p$-value $<0.002$.
\end{abstract}

Keywords: psychoeducation; postpartum blues; postpartum woman

Masa postpartum adalah salah satu masa transisi kritis dalam kehidupan perempuan baik dari sisi fisik dan psikologisnya. Masih rendahnya kualitas hidup perempuan khususnya pada ibu postpartum yang disebabkan oleh kurangnya kebutuhan masa postpartum berupa kebutuhan fisik, psikologis dan sosial. Wanita mempunyai peran yang sangat mendasar, dasar itulah maka dewasa ini penilaian kualitas hidup penting untuk mengukur ketepatan pemberian perawatan masa postpartum. Tujuan penelitian ini adalah untuk mengetahui faktor-faktor yang mempengaruhi kualitas hidup postpartum di wilayah kerja Puskesmas Mertoyudan I Kabupaten Magelang. Jenis penelitian ini adalah penenlitian kuantitatif dengan rancangan penelitian cross sectional. Teknik pengambilan sampel menggunakan accidental sampling. Jumlah sampel dalam penelitian ini 60 ibu nifas. Instrument penelitian berupa kuesioner karateristik faktor demografi (umur, pendidikan, status tinggal, pekerjaan, dan penghasilan), kuesioner obstetrik (paritas, jenis kelamin bayi yang dilahirkan, riwayat komplikasi kehamilan, riwayat abrtus, kehamilan diinginkan, dan faktor menyusui), dan kuesioner Postpartum Quality of Life (PQOL). Hasil penelitian dengan hasil uji statistik Chi-Square membuktikan bahwa ada pengaruh faktor demografi

*Korespondensi Penulis: Risky Puji Wulandari (email: riskypujiw@gmail.com), Mlangi Nogotirto, Jl. Siliwangi Jl. Ringroad Barat No. 63, Gamping, Sleman, Daerah Istimewa Yogyakarta 55592. 
meliputi variabel umur, variabel pendidikan, dan variabel penghasilan terhadap kualitas hidup postpartum dengan $p$-value $0,003<0,05$, $p$-value $0,001<0,05$, dan $p$-value $0,002<0,05$. Faktor obstetrik meliputi paritas, riwayat komplikasi, riwayat abortus, kehamilan diinginkan, dan faktor menyusui mempunyai pengaruh terhadap kualitas hidup postpartum dengan $p$-value $<0,050, p$-value $<003, p$-value $<0,040, p$-value $<0,000, p$-value $<0,017$, dan $p$-value $<0,002$.

Kata Kunci: kualitas hidup; postpartum baby blues; ibu nifas

\section{Pendahuluan}

Masa postpartum atau masa nifas adalah masa setelah plasenta lahir dan berakhir ketika alat-alat kandungan kembali seperti keadaan sebelum hamil selama kira-kira 6 minggu (Akýn et al., 2009). Periode pascamelahirkan adalah salah satu periode krisis dalam kehidupan seorang wanita dan periode yang sulit. Pasangan dengan anak pertama, akan menjadi pengalaman baru, baik istri maupun suami, sehingga dirasakan kebingungan, terutama istri yang merasakan perasaan cemas, takut, dan bahagia (Azale et al., 2018). Penelitian Webster et al. (2011) menemukan bahwa pengalaman masa nifas ibu tentang masalah kesehatan fisik dan psikologis dapat mempengaruhi kehidupan dan kesehatan masa depan ibu bahkan juga mempengaruhi anak yang baru lahir dan keluarga sekitar 68\%. Enam minggu masa nifas menandai akhir dari masa nifas berdasarkan asumsi bahwa wanita pulih secara fisik (Bodhare et al., 2015). Periode postpartum merubah beberapa karateristik ibu seperti kondisi psikologi, perubahan emosional, sosial, seksual, dan spiritual, hal ini dialami oleh semua ibu postpartum dan merupakan hal yang unik dalam periode kompleks kritis (Rowe et al., 2014).

Quality of Life (QOL) adalah penilaian multidimensi yang melibatkan aspek fungsi fisik, mental, dan sosial, dipengaruhi oleh evaluasi positif dan negatif yang subjektif. Kualitas hidup telah menjadi indikator yang valid dari hasil intervensi untuk menilai kesejahteraan dari kesehatan (Zubaran \& Foresti, 2011). Kualitas hidup ibu postpartum merujuk pada suatu keadaan emosional, sosial dan fisik ibu postpartum, termasuk kemampuan untuk berfungsi dalam tugas-tugas sehari-hari (Zhou et al., 2009). Kualitas hidup postpartum mengacu kepada kemampuan ibu untuk menikmati aktivitas kehidupan kesehariannya (Lara-Cinisomo et al., 2018). Studi melaporkan bahwa masa postpartum berpengaruh signifikan terhadap kesehatan fisik dan mental ibu dengan berbagai masalah seperti kelelahan, sakit kepala, sakit punggung dan pinggang, pengeluaran ASI tidak lancar, kecemasan, stress, insmonia, sembelit, perdarahan, inkontinensia urine, anoreksia, postpartum blues dan depresi postpartum (Leight et al., 2011).

Penelitian Ribeiro et al. (2015) yang dilakukan di Brazil menyatakan bahwa sangat tepat untuk meningkatkan kesejahteraan fisik, mental dan sosial pada ibu postpartum demi peningkatan kualitas hidupnya (Ribeiro et al., 2015).

Penelitian Leight et al. (2011) menemukan bahwa perkiraan prevalensi PPD di AS, Inggris dan Australia berkisar dari $7 \%-20 \%$, dengan sebagian besar penelitian menunjukkan angka antara $10 \%-15 \%$.Faktor resiko yang signifikan untuk PPD termasuk riwayat depresi sebelum atau selama kehamilan, kecemasan selama 
kehamilan, mengalami peristiwa kehidupan yang penuh tekanan selama kehamilan atau masa nifas awal, tingkat dukungan sosial yang rendah, sosial ekonomi rendah yakni kelompok resiko tertentu, pekerjaan, tingkat pendidikan rendah, keluhan fisik, rendahnya pendidikan, status soial ekonomi rendah, sangat mempengaruhi rendahnya kualitas hidup ibu postpartum di Brazil (Leight et al., 2011).

Penelitian Fenwick et al. (2015) menemukan bahwa selama masa postpartum, wanita postnatal yang menerima psikoedukasi melaporkan bahwa bantuan keputusan dari tenaga kesehatan membantu mengurangi rasa takut dan meningkatkan kepuasan selama masa postpartum dalam menghadapi aktifitas dan peran barunya sebagai ibu ( $53 \%$ vs $37 \%, p=0,02$ ) (Fenwick et al., 2015). Perawatan pada masa postpartum bagi ibu dan lebih daripada sekedar pemeriksaan kesehatan fisik. Tujuan yang lebih penting adalah menilai kesiapan mental dan psikologis ibu dalam perawatan bayinya (Bosch et al., 2018).

Kualitas hidup ibu postpartum tergantung dari kondisi yang menyertainya dan erat hubungannya dengan kondisi mental dan fisik ibu dalam periode postpartum. Menilai kualitas hidup dalam periode postpartum akan memungkinkan seorang ibu untuk melakukan evaluasi diri terhadap kondisi pasca persalinannya dan juga akan membantu penyedia layanan kesehatan dalam menilai kondisi kesehatan ibu secara menyeluruh baik fisik dan mental. Selama masa ini, ibu diharapkan dapat menyampaikan secara teratur serangkaian gejala psikologis maupun fisik seperti kesulitan perawatan anak, keterbatasan fisik, kelelahan, dan nyeri. Meskipun gejala-gejala ini sering dianggap sementara atau tidak me- netap, namun hal ini sangat berkaitan dengan penilaian kualitas hidup ibu postpartum (Top \& Karaçam, 2016).

Padahal kesehatan mental seringkali tidak diutamakan sebagai masalah di negara-negara miskin maupun berkembang di mana akses ke nutrisi dasar dan perawatan kesehatan tidak konsisten, bukti menunjukkan bahwa depresi pascapersalinan mungkin lebih umum dan lebih parah bagi wanita dan anak-anak mereka di negara-negara berpenghasilan rendah. Data terbatas dari negara dengan sumber daya terbatas menunjukkan bahwa tingkat depresi pada ibu yang memiliki bayi terjadi lebih dari $25 \%$. Perpotongan faktor budaya, antarpribadi dan sosial ekonomi yang rendah dapat juga memberikan risiko PPD yang signifikan: dalam sebuah penelitian di Goa, India, risiko depresi setelah melahirkan meningkat dengan tingkat status ekonomi, kekerasan dalam perkawinan, dan jenis kelamin bayi perempuan (Leight et al., 2011).

Puskesmas Mertoyudan I mempunyai cakupan KF (Kunjungan Nifas) paling rendah sebesar $76,9 \%$, hal ini belum memenuhi target SPM (Standar Pelayanan Minimal) Bidang Kesehatan sebesar $90 \%$. Berdasarkan hasil studi pendahuluan yang dilakukan oleh peneliti di lapangan pada bulan Februari 2018 dengan metode wawancara dengan bidan koordinator didapatkan informasi bahwa cakupan kunjungan nifas yang belum sesuai target diakibatkan karena kurangnya kesadaran ibu dan rendahnya dukungan dari suami maupun keluarga untk melakukan pemeriksaan kesehatan setelah persalinan.

Penelitian mengenai kualitas hidup di Indonesia memang belum menjadi sebuah stan- 
dar dalam pelayanan kesehatan, tenaga kesehatan masih berfokus pada kesehatan fisik ibu masa posptpartum. Selain itu penilaian kualitas hidup tidak pernah dilakukan sebelumnya, padahal dengan penilaian kualitas hidup postpartum mampu megetahui pemberian perawatan masa nifas yang tepat diberikan oleh bidan. Hal ini juga erat kaitannya dengan holistic care yaitu pelayanan kesehatan yang mana lebih memperhatikan keutuhan aspek kehidupan sebagai manusia yang meliputi kehidupan jasmani, mental, sosial, spiritual yang saling mempengaruhi. Pada Tujuan penelitian ini adalah untuk mengetahui faktor-faktor apa saja yang berpengaruh terhadap kualitas hidup postpartum di Puskesmas Mertoyudan I Kabupaten Magelang.

\section{Metode}

Desain penelitian yang digunakan pada penelitian ini adalah survey analitik dengan pendekatan cross sectional. Populasi dari penelitian ini adalah semua ibu nifas di Wilayah Kerja Puskesmas Mertoyudan I Kabupaten Magelang sebanyak 75 ibu nifas setiap bulannya. Teknik pengambilan sampel menggunakan accidental sampling dengan penentuan jumlah sampel menggunakan rumus Isaac dan Michael taraf kesalahan $5 \%$ dari jumlah populasi didapatkan besar sampel sebesar 60 responden. Penelitian ini dilakukan selama 2 bulan (Maret-April 2018). Kriteria inklusi penelitian ini adalah semua ibu nifas yang melahirkan secara normal, kondisi bayi lahir sehat tidak ada kelainan dan tinggal di wilayah Puskesmas Mertoyudan I Kabupaten Magelang. Kriteria ekslusi yaitu ibu yang melahirkan secara SC, ibu yang mengalami gangguan psikis, dan menolak untuk dijadikan responden.
Instrumen pengambilan data dalam penelitian ini menggunakan data primer (kuesioner). Variabel bebas (variable independent) adalah faktor demografi meliputi umur, pendidikan, status tinggal, pekerjaan, dan penghasilan, faktor obstetrik meliputi paritas, jenis kelamin bayi, riwayat komplikasi, riwayat abortus atau kematian bayi, kehamilan diinginkan, dan menyusui. Variabel terikat (variable dependent) adalah kualitas hidup postpartum. Instrumen pengkuran kualitas hidup dengan Postpartum Quality of Life (PQOL) berjumlah 40 item dari Zhou et.al (2009) yag diterjemahkan ke dalam bahasa Indonesia. Penilaian kualitas hidup dilakukan 42 hari (6 minggu) masa postpartum. Dalam penelitian ini, uji validitas dan reliabilitas tidak dilakukan karena telah dilakukan oleh peneliti sebelumnya dengan analisis konsistensi internal, hasil nilai Cornbach's $\alpha>0,7$. Kuesioner Instrumen Postpartum Quality of Life (PQOL) milik Zhou et al merupakan desain dari prosedur pengembangan standar spesifik WHOQOL (World Health Organization Quality of Life) yang telah tervalidasi oleh WHO (Zhou, 2010).

Analisis univariat dilakukan dengan statistik deskriptif untuk mendeskripsikan karakteristik setiap variabel penelitian. Analisis bivariat menggunakan uji Chi-Square, perhitungan ChiSquare menggunakan ketentuan derajat kesalahan ( $\alpha$ ) 5\% atau 0,05 Ha diterima jika nilai $\operatorname{signifikan}(p)<\alpha$.

Ethical clearance dalam penelitian ini telah dimintakan ke LPPM Universitas 'Aisyiyah Yogyakarta dengan nomor 553/KEP-UNISA/V/2018.

\section{Hasil dan Pembahasan}

Responden (71,7\%). Usia resiko tinggi $<20$ tahun dan $>35$ tahun sebanyak 17 responden 
(28,3\%). Karakteristik pendidikan responden didapatkan hasil bahwa sebagian besar responden berpendidikan menengah (SMA, MA, SMK) yaitu sebanyak 41 responden (68,3\%) namun ada yang berpendidikan SD (5,0\%). Mayoritas status tinggal ibu yaitu tinggal serumah 1 KK sebesar 38 responden (63,3\%), 22 responden $(36,7 \%)$ menyatakan masih tinggal dengan ibu atau mertua dan atau saudara lainnya. Mayoritas responden tidak bekerja sejumlah 43 responden $(71,7 \%)$, sisanya bekerja dirumah dan diluar rumah. Presentase pendapatan rumah tangga terbanyak Rp. UMR $<1.590 .000$ yaitu $56,7 \%$, dan pendapatan diatas UMR $\geq 1.600 .000$ sejumlah $43,3 \%$.

Faktor obstetrik meliputi paritas responden yaitu primipara sebanyak 24 responden (40\%), 21 responden (35\%) multipara, dan 15 responden (25\%) grandemultipara. Jenis kelamin bayi yang dilahirkan perempuan sejumlah 31 (51,7\%) dan jenis kelamin laki-laki sejumlah 29 (48,3\%). Sebagian besar responden tidak pernah mengalami riwayat komplikasi pada kehamilan ini atau kehamilan yang lalu sebanyak 39 responden (65\%) dan yang pernah mengalami riwayat komplikasi sebanyak 21 responden (35\%). Responden yang pernah mengalami riwayat abortus atau kematian bayi sebelumnya sejumlah 14 responden $(23,3 \%)$ dan yang tidak pernah mengalai riwayat abortus atau kematian bayi sejumlah 46 responden (76,7\%). Mayoritas kehamilan ini adalah kehamilan yang dinantikan oleh responden dan keluarga yaitu sebesar 53 responden (88,3\%) namun masih ada responden yang menyatakan bahwa kehamilan ini tidak diinginkannya karena tidak direncanakan sebesar 7 responden (11,7\%). Frekuensi menyusui pada responden sebagian besar menyusui bayinya sejumlah 42 responden (70\%) dan yang tidak menyusui bayinya sejumlah 18 responden (30\%). Karateristik kualitas hidup responden dengan skor nilai $\geq 110$ atau kualitas hidup baik hanya sejumlah 25 responden (41,7\%) sedangkan responden yang memperoleh skor $<110$ atau kualitas hidup rendah lebih banyak yaitu sejumlah 35 responden (58,3\%).

Hasil analisis data pada Tabel 1 menunjukkan bahwa responden dengan umur reproduktif 2135 tahun dengan skor nilai kualitas hidup baik sejumlah 23 responden (38,3\%). Hasil uji ChiSquare yaitu $p$-value menunjukan hasil 0,008 sehingga dapat disimpulkan bahwa $p$-values $0,008<0,05$ dan terdapat hubungan umur dengan kualitas hidup postpartum. Nilai koefisien kontingensi didapatkan hasil bahwa $\mathrm{C}=0,356$ yaitu kekuatan tingkat hubungan koefisien kontingensi adalah rendah (0,20-0,399). Usia merupakan salah satu faktor yang mempengaruhi

Tabel 1. Korelasi Umur dengan Kualitas Hidup di Wilayah Kerja

Puskesmas Mertoyudan I Magelang

\begin{tabular}{|c|c|c|c|c|c|c|c|c|}
\hline \multirow{3}{*}{ Umur } & \multicolumn{4}{|c|}{ Kualitas Hidup Postpartum } & \multirow{2}{*}{\multicolumn{2}{|c|}{ Total }} & \multirow{3}{*}{$P$-value } & \multirow{3}{*}{ C } \\
\hline & \multicolumn{2}{|c|}{ Baik } & \multicolumn{2}{|c|}{ Rendah } & & & & \\
\hline & $f$ & $\%$ & $f$ & $\%$ & $f$ & $\%$ & & \\
\hline 21-35 tahun & 23 & 38,33 & 20 & 33,33 & 43 & 71,67 & \multirow{3}{*}{0,003} & \multirow{3}{*}{0,356} \\
\hline$<20$ dan $>35$ & 2 & 3,33 & 15 & 25,0 & 17 & 28,33 & & \\
\hline Total & 25 & 41,66 & 35 & 58,33 & 60 & 100 & & \\
\hline
\end{tabular}


kualitas hidup. Berdasarkan rentang usia reproduksi yang sehat proses melahirkan pada masa usia tersebut berada kondisi minimal untuk terjadinya risiko. Pada usia tersebut diikuti telah terjadi kematangan organ reproduksi, yang diikuti kematangan kondisi emosional, maupun sosial. Usia reproduktif meningkatkan kesiapan fisik dan mentalnya dalam perawatan anak sehingga hal ini berpengaruh terhadap kualitas hidup (Bosch et al., 2018). Umur berhubungan signifikan dengan kualitas hidup ibu postpartum di Turki dengan nilai $p$-value 0,034 (Lara-Cinisomo et al., 2018). Kesiapan menjadi seorang ibu ternyata juga mempengaruhi kualitas hidup postpartum seorang ibu. Kurangnya kesiapan untuk memiliki anak, tekanan kecemasan akan kemampuannya untuk memberikan perawatan pada bayinya, maupun risiko yang bisa dialami ibu selama hamil, bersalin dan nifas, dapat terjadi pada perempuan usia $<20$ tahun sehingga mempengaruhi kualitas hidup postpartum (Norman et al., 2010).

Tabel 2 menunjukkan responden berpendidikan perguruan tinggi mayoritas memperoleh skor kualitas hidup baik sejumlah 6 responden (25\%) dan kualitas hidup rendah sejumlah 2 responden (3,3\%). Hasil uji Chi-Square yaitu $p$ - value menunjukan hasil 0,008, dapat disimpulkan bahwa $p$-values 0,008 $<0,05$ artinya terdapat pengaruh pendidikaan terhadap kualitas hidup postpartum. Nilai koefisien kontingensi didapatkan hasil bahwa $\mathrm{C}=0,407$ yaitu kekuatan tingkat hubungan koefisien kontingensi adalah sedang $(0,40-0,599)$.

Berdasarkan analisis deskrptif didapatkan bahwa baik pendidikan rendah maupun tinggi memiliki peluang untuk memperoleh skor kualitas hidup yang rendah. Akan tetapi, hanya ada 2 responden berpendidikan perguruan tinggi yang memperoleh skor kualitas hidup rendah dibandingkan dengan responden dengan pendidikan menengah sebanya 22 responden $(36,7 \%)$ memperoleh skor kualitas hidup rendah.

Sejalan dengan penelitian Akyn (2010) menyatakan bahwa pendidikan sangat berpengaruh signifikan terhadap kualitas hidup dengan nilai $p$-value 0,000 . ibu yang berpendidikan tinggi mempunyai pengetahuan dan kepercayaan diri lebih baik di banding ibu dengan pendidikan yang lebih rendah, selain itu pendidikan juga memberikan pengetahuan yang berhubungan dengan kesehatan seorang perempuan (Torkan et al., 2009).

Tabel 2. Hubungan Pendidikan dengan Kualitas Hidup di Wilayah Kerja Puskesmas Mertoyudan I Kabupaten Magelang

\begin{tabular}{ccccccccc}
\hline & \multicolumn{3}{c}{ Kualitas Hidup Postpartum } & & \multirow{2}{*}{ Total } & \multirow{2}{*}{ P-value } & $\mathrm{C}$ \\
\cline { 2 - 6 } Pendidikan & \multicolumn{3}{c}{ Baik } & \multicolumn{2}{c}{ Rendah } & & & \\
\cline { 2 - 6 } & $\mathrm{f}$ & $\%$ & $\mathrm{f}$ & $\%$ & $\mathrm{f}$ & $\%$ & & \\
\hline SD & 0 & 0 & 3 & 5,0 & 3 & 5,0 & & \\
SMP & 0 & 0 & 8 & 13,3 & 8 & 13,3 & & 0,407 \\
SMA & 19 & 31,67 & 22 & 36,67 & 41 & 68,33 & 0,008 & \\
PT & 6 & 10,0 & 2 & 3,33 & 8 & 13,33 & & \\
Total & 25 & 41,67 & 35 & 58,33 & 60 & 100 & & \\
\hline
\end{tabular}


Penelitian Baghirzada et al. (2013) menunjukkan bahwa pengetahuan yang didapatkan ibu dari pendidikan formalnya mampu meningkatkan kemampuan fisik, kemampuan perawatan anak, pengelolaan rasa sakit dan energi yang berpengarub terhadap kualitas hidup ibu.

Penelitian ini juga sejalan dengan penelitian Ribeiro et al. (2015) yang menyatakan bahwa peningkatan pengetahuan mengenai postpartum, pengalaman ibu dapat membantu mengembangkan intervensi kesehatan untuk meningkatkan kualitas hidup populasi ibu postpartum di Brazil.

Tabel 3 menunjukkan bahwa responden yang tinggal $>1 \mathrm{KK}$ hanya mendapatkan skor nilai kualitas hidup baik sejumlah 6 responden (10\%) dan 16 responden (26,6\%) mendapatkan skor nilai kualitas hidup rendah. Responden yang tinggal serumah $1 \mathrm{KK}$ hanya bersama suami berjumlah sama 19 responden (31,7\%) yang menperoleh skor nilai kualitas hidup baik maupun rendah. Hasil uji Chi-Square yaitu $p$-value menunjukan hasil 0,085 >0,05, yang artinya tidak cukup data untuk menerima Ha. Ho diterima sehingga tidak terdapat pengaruh status tinggal dengan kualitas hidup postpartum. Sependapat dengan penelitian Miyake et al. (2006) bahwa status tinggal bersama ataupun status kepemilikan rumah tidak berpengaruh terhadap kualitas hidup. Ibu yang tinggal satu rumah dengan lebih dari 1 kepala keluarga mampu memberikan banyak dukungan yang mempengaruhi kondisi psikologis ibu. Tidak berbeda dengan seorang ibu yang tinggal hanya dengan satu kepala keluarga yaitu suami juga bisa saling bahu-membahu dalam urusan rumah tangga (Ribeiro et al., 2015).

Hasil analisis pada Tabel 4 menunjukkan bahwa responden yang bekerja dan memperoleh skor kualitas hidup baik sebesar 13,3\% sedangkan responden yang tidak bekerja sebesar $28,3 \%$.

Sembilan responden (15\%) ibu pekerja mendapat kualitas hidup yang rendah dan 26 responden $(43,4 \%)$ IRT memperoleh skor nilai kualitas hidup rendah. Hasil uji Chi-Square yaitu $p$ value menunjukan hasil 0,0594 >0,05, yang artinya $\mathrm{Ha}$ ditolak, Ha diterima yaitu tidak terdapat pengaruh pekerjaan dengan kualitas hidup postpartum. Pekerjaan secara hakikatnya adalah aktivitas yang rutin dilakukan oleh ibu. Pekerjaan apa saja yang dilakukan oleh ibu baik beraktivitas di instansi pemerintah, swasta atau

Tabel 3. Korelasi Status Tinggal dengan Kualitas Hidup di Wilayah Kerja Puskesmas Mertoyudan I Kabupaten Magelang

\begin{tabular}{|c|c|c|c|c|c|c|c|c|}
\hline \multirow{3}{*}{ Status Tinggal } & \multicolumn{4}{|c|}{ Kualitas Hidup Postpartum } & \multirow{2}{*}{\multicolumn{2}{|c|}{ Total }} & \multirow{3}{*}{$P$-value } & \multirow{3}{*}{ C } \\
\hline & \multicolumn{2}{|c|}{ Baik } & \multicolumn{2}{|c|}{ Rendah } & & & & \\
\hline & $f$ & $\%$ & $f$ & $\%$ & $f$ & $\%$ & & \\
\hline $1 \mathrm{KK}$ & 19 & 31,67 & 19 & 31,67 & 38 & 63,33 & \multirow{3}{*}{0,085} & \multirow{3}{*}{0,217} \\
\hline$>1 \mathrm{KK}$ & 6 & 10,0 & 16 & 26,67 & 22 & 36,67 & & \\
\hline Total & 25 & 41,67 & 35 & 58,34 & 60 & 100 & & \\
\hline
\end{tabular}


Tabel 4. Korelasi Pekerjaan dengan Kualitas Hidup di Wilayah Kerja Puskesmas Mertoyudan I Kabupaten Magelang

\begin{tabular}{|c|c|c|c|c|c|c|c|c|}
\hline \multirow{3}{*}{ Pekerjaan } & \multicolumn{4}{|c|}{ Kualitas Hidup Postpartum } & \multirow{2}{*}{\multicolumn{2}{|c|}{ Total }} & \multirow{3}{*}{ P-value } & \multirow{3}{*}{ C } \\
\hline & \multicolumn{2}{|c|}{ Baik } & \multicolumn{2}{|c|}{ Rendah } & & & & \\
\hline & $f$ & $\%$ & $f$ & $\%$ & $\mathrm{f}$ & $\%$ & & \\
\hline Bekerja & 8 & 13,33 & 9 & 15,0 & 17 & 28,3 & \multirow{3}{*}{0,069} & \multirow{3}{*}{0,594} \\
\hline Tidak Bekerja & 17 & 28,33 & 26 & 43,33 & 43 & 71,7 & & \\
\hline Total & 25 & 41,66 & 35 & 58,33 & 60 & 100 & & \\
\hline
\end{tabular}

Tabel 5. Korelasi Penghasilan dengan Kualitas Hidup di Wilayah Kerja Puskesmas Mertoyudan I Kabupaten Magelang

\begin{tabular}{|c|c|c|c|c|c|c|c|c|}
\hline \multirow{3}{*}{ Penghasilan } & \multicolumn{4}{|c|}{ Kualitas Hidup Postpartum } & \multirow{2}{*}{\multicolumn{2}{|c|}{ Total }} & \multirow{3}{*}{$P$-value } & \multirow{3}{*}{ C } \\
\hline & \multicolumn{2}{|c|}{ Baik } & \multicolumn{2}{|c|}{ Rendah } & & & & \\
\hline & $f$ & $\%$ & $f$ & $\%$ & $f$ & $\%$ & & \\
\hline Di atas UMR & 15 & 25,0 & 11 & 18,33 & 26 & 43,33 & & \\
\hline $\begin{array}{l}\text { Dibawah } \\
\text { UMR }\end{array}$ & 10 & 16,67 & 24 & 40,0 & 34 & 56,67 & 0,028 & 0,273 \\
\hline Total & 25 & 41,67 & 35 & 58,33 & 60 & 100 & & \\
\hline
\end{tabular}

sebagai ibu rumah tangga cenderung tidak berpengaruh pada kondisi psikologis saat melahirkan maupun saat setelah melahirkan, namun cenderung berhubungan dengan pendapatan keluarga (Akýn et al., 2009).

Tabel 5 menunjukkan bahwa kualitas hidup baik diperoleh responden yang berpenghasilan rumah tangga di atas UMR sejumlah 15 responden (25\%) dan responden yang berpenghasilan $<U M R$ sejumlah 10 responden $(16,7 \%)$. Hasil uji Chi-Square yaitu p-value menunjukan hasil 0,028 , dapat disimpulkan bahwa $p$-values $0,028<0,05$, artinya terdapat pengaruh penghasilan terhadap kualitas hidup postpartum. Nilai koefisien kontingensi didapatkan hasil bahwa $\mathrm{C}=0,273$, yaitu kekuatan tingkat hubungan koefisien kontingensi adalah rendah $(0,20-0,399)$.

Penelitian ini sejalan dengan penelitian Baghirzada et al. (2013) bahwa status ekonomi yang rendah meningkatan risiko berbagai macam masalah kesehatan setelah melahirkan dan juga pelayanan kesehatan masa postpartum. Berbagai problem selama masa postpartum karena masalah ekonomi sering berimbas kekhawatiran ibu akan masa depan anaknya (Webster et al., 2011).

Pada Tabel 6 menunjukkan bahwa karateristik obstetrik responden dengan paritas primipara paling banyak mendapatkan skor-skor nilai kualitas hidup baik sejumlah 15 responden (25\%), responden paritas multipara dengan skor nlai kualitas hidup baik hanya sejumlah 9 responden (15\%), sedangkan responden dengan paritas grandemultipara yang memperoleh skor kualitas hidup baik hanya 1 responden (1,67\%). Hasil uji Chi-Square yaitu $p$-value menunjukan hasil 0,003, dapat disimpulkan bahwa p-values 0,003 $<0,05$ artinya terdapat pengaruh paritas terhadap kualitas hidup postpartum. Nilai koefisien kontingensi didapatkan hasil bahwa $\mathrm{C}=0,406$ yaitu kekuatan tingkat hubungan koefisien kontingensi adalah sedang $(0,40-0,599)$. 
Faktor demografi dan obstetrik dalam mempengaruhi kualitas hidup postpartum

Tabel 6. Korelasi Paritas dengan Kualitas Hidup di

Wilayah Kerja Puskesmas Mertoyudan I Kabupaten Magelang

\begin{tabular}{ccccccccc}
\hline \multirow{2}{*}{ Paritas } & \multicolumn{3}{c}{ Kualitas Hidup Postpartum } & & \multirow{2}{*}{ Total } & \multirow{2}{*}{ P-value } & C \\
\cline { 2 - 6 } & \multicolumn{3}{c}{ Baik } & \multicolumn{2}{c}{ Rendah } & & & \\
\cline { 2 - 7 } & $\mathrm{f}$ & $\%$ & $\mathrm{f}$ & $\%$ & $\mathrm{f}$ & $\%$ & & \\
\hline Primipara & 15 & 25,0 & 9 & 15,0 & 24 & 40,0 & & \\
Multipara & 9 & 15,0 & 12 & 20,0 & 21 & 35,0 & 0,003 & \\
Grandemultipara & 1 & 1,67 & 14 & 23,33 & 15 & 25,0 & & \\
Total & 25 & 41,67 & 35 & 58,33 & 60 & 100 & & \\
\hline
\end{tabular}

Tabel 7. Korelasi Jenis Kelamin Bayi dengan Kualitas Hidup di Wilayah Kerja Puskesmas Mertoyudan I Kabupaten Magelang

\begin{tabular}{|c|c|c|c|c|c|c|c|c|}
\hline \multirow{3}{*}{$\begin{array}{c}\text { Jenis Kelamin } \\
\text { Bayi }\end{array}$} & \multicolumn{4}{|c|}{ Kualitas Hidup Postpartum } & \multirow{2}{*}{\multicolumn{2}{|c|}{ Total }} & \multirow{3}{*}{ P-value } & \multirow{3}{*}{ C } \\
\hline & \multicolumn{2}{|c|}{ Baik } & \multicolumn{2}{|c|}{ Rendah } & & & & \\
\hline & $f$ & $\%$ & $f$ & $\%$ & $f$ & $\%$ & & \\
\hline Laki-Laki & 14 & 23,33 & 15 & 25,0 & 29 & 48,33 & \multirow{3}{*}{0,315} & \multirow{3}{*}{0,129} \\
\hline Perempuan & 11 & 18,33 & 20 & 33,33 & 31 & 51,67 & & \\
\hline Total & 25 & 41,66 & 35 & 58,33 & 60 & 100 & & \\
\hline
\end{tabular}

Penelitian Carlander et al. (2015) menyatakan bahwa paritas berhubungan dengan kualitas hidup postpartum. Proses kehamilan senantiasa memberikan pengalaman yang berbeda pada setiap ibu. bagi multigravida, kualitas hidupnya bisa berdasarkan pengalaman pada riwayat kehamilan yang lalu sehingga memicu suatu persepsi yang berkelanjutan ke kehamilan yang berikutnya. Sejalan dengan penelitian Prick et al. (2015) juga menyatakan bahwa paritas berpengaruh signifikan terhadap kualitas hidup postpartum dengan $p$-value 0,000 . Pada primigravida kualitas hidup lebih menunjukkan pada kesiapan ibu untuk melahirkan dan merawat anak. Ibu yang belum mempunyai pengalaman melahirkan akan menjalani transisi peran barunya sebagai seorang ibu, sehingga menuntut proses adaptasi yang berpengaruh terhadap kualitas hidup ibu postpartum (Alderdice et al., 2013). Pada ibu grandemultipara mungkin memiliki perasaan tidak segembira seperti ketika melahirkan anak pertamanya, akan tetapi pada ibu yang telah lebih $3 x$ melahirkan ini mempunyai pengalaman dalam persalinan dan perawatan anak.

Tabel 7 menunjukkan bahwa responden yang melahirkan bayi laki-laki maupun perempuan rata-rata mendapatkan skor nilai kualitas hidup baik sejumlah 14 responden $(23,3 \%)$ dan 11 responden (18,3\%) dan yang Hasil uji Chi-Square yaitu $p$-value menunjukan hasil 0,315 , dapat disimpulkan bahwa $p$-values 0,0315>0,05 artinya Ha ditolak dan Ho diterima yaitu tidak terdapat pengaruh jenis kelamin bayi terhadap kualitas hidup postpartum. Jenis kelamin tidak berhubungan dengan kualitas hidup postpartum. Kelahiran anak laki-laki ataupun anak perempuan yang sehat dan len lengkap memberikan kebahagiaan yang sama (Carlander et al., 2015). 
Tabel 8. Korelasi Riwayat Komplikasi selama Kehamilan terhadap Kualitas Hidup di Wilayah Kerja Puskesmas Mertoyudan I Kabupaten Magelang

\begin{tabular}{|c|c|c|c|c|c|c|c|c|}
\hline \multirow{3}{*}{$\begin{array}{l}\text { Riwayat } \\
\text { Komplikasi }\end{array}$} & \multicolumn{4}{|c|}{ Kualitas Hidup Postpartum } & \multirow{2}{*}{\multicolumn{2}{|c|}{ Total }} & \multirow{3}{*}{ P-value } & \multirow{3}{*}{ C } \\
\hline & \multicolumn{2}{|c|}{ Baik } & \multicolumn{2}{|c|}{ Rendah } & & & & \\
\hline & $f$ & $\%$ & $f$ & $\%$ & $f$ & $\%$ & & \\
\hline Tidak & 20 & 33,3 & 19 & 31,67 & 39 & 65,0 & \multirow{3}{*}{0,040} & \multirow{3}{*}{0,257} \\
\hline Ya & 5 & 8,3 & 16 & 26,67 & 21 & 25,0 & & \\
\hline Total & 25 & 41,66 & 35 & 58,34 & 60 & 100 & & \\
\hline
\end{tabular}

Tabel 9. Korelasi Riwayat Abortus terhadap Kualitas Hidup di Wilayah Kerja Puskesmas Mertoyudan I Kabupaten Magelang

\begin{tabular}{|c|c|c|c|c|c|c|c|c|}
\hline \multirow{3}{*}{$\begin{array}{c}\text { Riwayat } \\
\text { Komplikasi }\end{array}$} & \multicolumn{4}{|c|}{ Kualitas Hidup Postpartum } & \multirow{2}{*}{\multicolumn{2}{|c|}{ Total }} & \multirow{3}{*}{$P$-value } & \multirow{3}{*}{ C } \\
\hline & \multicolumn{2}{|c|}{ Baik } & \multicolumn{2}{|c|}{ Rendah } & & & & \\
\hline & $f$ & $\%$ & $f$ & $\%$ & $f$ & $\%$ & & \\
\hline Tidak & 25 & 41,67 & 21 & 35,0 & 46 & 76,67 & \multirow{3}{*}{0,000} & \multirow{3}{*}{0,423} \\
\hline Ya & 0 & 0 & 14 & 23,33 & 14 & 23,33 & & \\
\hline Total & 25 & 41,67 & 35 & 58,33 & 60 & 100 & & \\
\hline
\end{tabular}

Riwayat komplikasi kehamilan berpengaruh terhadap kualitas hidup postpartum dengan nilai $p$-value menunjukan hasil $0,040<0,05$. Pada Tabel 8 menunjukkan bahwa responden yang tidak mengalami riwayat komplikasi selama kehamilannya mendapatkan skor nilai kualitas hidup baik sejumlah 20 responden (33,3\%), berbeda dengan responden yang mengalami riwayat komplikasi selama kehamilannya memperoleh skor nilai kualitas hidup baik hanya sejumlah 5 responden (8,3\%).

Nilai koefisien kontingensi didapatkan hasil bahwa $\mathrm{C}=0,257$ yaitu kekuatan tingkat hubungan koefisien kontingensi adalah rendah (0,20-0,399). Penelitian ini sejalan dengan penelitian Van Den Bosch (2018) yang menyatakan bahwa komplikasi selama kehamilan berpenharuh terhadap skor kualitas hidup yang rendah pada hasil pengukuran pada 6 minggu postpartum. Riwayat komplikasi selama kehamilan seperti mual, muntah, lemas, perut begah, sembelit, preeklampsia, dan anemia mampu mempe- ngaruhi pengalaman persalinan ibu. selain itu, riwayat komplikasi selama kehamilan menyebabkan terbatasnya ibu untuk melakukan aktivitas fisik selama masa postpartum, hal ini berdampak pada penilaian kualitas hidup ibu. Penelitian Akýn et al. (2009) menyatakan bahwa pengaruh gangguan hipertensi, diabetes kehamilan, dan kelahiran prematur sebagai faktor risiko yang berhubungan dengan kualitas hidup dan gejala depresi selama kehamilan dan postpartum akhir.

Tabel 9 menunjukkan bahwa responden yang tidak pernah mengalami riwayat abortus atau kematian bayi mendapatkan skor nilai kualitas hidup baik sejumlah 25 responden (41,67\%), berbeda dengan responden yang pernah mengalami riwayat abortus tidak ada yang memperoleh skor nilai kualitas hidup. Hasil uji Chi-Square yaitu $p$-value menunjukan hasil 0,000, dapat disimpulkan bahwa $p$-values $0,0000<0,05$ artinya Ha diterima yaitu ada pengaruh riwayat abortus atau kematian bayi terhadap kualitas 
Faktor demografi dan obstetrik dalam mempengaruhi kualitas hidup postpartum

Tabel 10. Korelasi Kehamilan Diinginkan terhadap Kualitas Hidup di Wilayah Kerja Puskesmas Mertoyudan I Kabupaten Magelang

\begin{tabular}{|c|c|c|c|c|c|c|c|c|}
\hline \multirow{3}{*}{$\begin{array}{l}\text { Kehamilan } \\
\text { Diinginkan }\end{array}$} & \multicolumn{4}{|c|}{ Kualitas Hidup Postpartum } & \multirow{2}{*}{\multicolumn{2}{|c|}{ Total }} & \multirow{3}{*}{ P-value } & \multirow{3}{*}{ C } \\
\hline & \multicolumn{2}{|c|}{ Baik } & \multicolumn{2}{|c|}{ Rendah } & & & & \\
\hline & $f$ & $\%$ & $f$ & $\%$ & $f$ & $\%$ & & \\
\hline Ya & 25 & 41,66 & 28 & 46,67 & 53 & 88,33 & \multirow{3}{*}{0,017} & \multirow{3}{*}{0,294} \\
\hline Tidak & 0 & 0 & 7 & 11,67 & 7 & 11,67 & & \\
\hline Total & 25 & 41,67 & 35 & 58,34 & 60 & 100 & & \\
\hline
\end{tabular}

Tabel 11. Korelasi Faktor Menyusui terhadap Kualitas Hidup di Wilayah Kerja Puskesmas Mertoyudan I Kabupaten Magelang

\begin{tabular}{cccccccccc}
\hline \multirow{2}{*}{$\begin{array}{c}\text { Faktor } \\
\text { Menyusui }\end{array}$} & \multicolumn{3}{c}{ Kualitas Hidup Postpartum } & \multicolumn{2}{c}{ Total } & \multirow{2}{*}{ P-value } & C \\
\cline { 2 - 6 } & \multicolumn{3}{c}{ Baik } & \multicolumn{2}{c}{ Rendah } & & & \\
\cline { 2 - 7 } & $\mathrm{f}$ & $\%$ & $\mathrm{f}$ & $\%$ & $\mathrm{f}$ & $\%$ & & \\
\hline Ya & 23 & 38,33 & 19 & 31,67 & 42 & 70,0 & \multirow{2}{*}{0,002} & 0,376 \\
Tidak & 2 & 3,33 & 16 & 26,67 & 18 & 30,0 & & \\
Total & 25 & 41,67 & 35 & 58,34 & 60 & 100 & & \\
\hline
\end{tabular}

hidup postpartum. Nilai koefisien kontingensi didapatkan hasil bahwa $\mathrm{C}=0,423$ yaitu kekuatan tingkat hubungan koefisien kontingensi adalah sedang $(0,40-0,599)$.

Sejalan dengan penelitian Baghirzada et al. (2013) dan Tychey et al. (2008) riwayat abortus berpengaruh negatif terhadap kualitas hidup, ibu yang pernah mengalami riwayat abortus atau kematian bayi mempunyai pengalaman kehamilan dan persalinan yang berbeda. Ibu akan lebih cemas dan khawatir akan masa kehamilan, persalinan, dan perawatan anaknya.

Tabel 10 menunjukkan bahwa responden yang menyatakan bahwa kehamilan ini adalah kehamilan yang diinginkannya mendapatkan skor nilai kualitas hidup baik sejumlah 25 responden $(41,66 \%)$ berbeda halnya dengan responden yang menyatakan bahwa kehamilan ini merupakan kehamilan yang tidak diinginkan atau tidak direncanakan tidak ada yang memperoleh skor nilai kualitas hidup baik, bahkan sebanyak 7 responden $(11,67)$ memperoleh skor kualitas hidup rendah. Hasil uji Chi-Square yaitu $p$-value menunjukan hasil 0,017 , dapat disimpulkan bahwa $p$-values 0,017 <0,05 artinya Ha diterima dan Ho ditolak yaitu ada pengaruh kehamilan yang diinginkan terhadap kualitas hidup postpartum. Nilai koefisien kontingensi didapatkan hasil bahwa $\mathrm{C}=0,294$ yaitu kekuatan tingkat hubungan koefisien kontingensi adalah rendah $(0,20-0,399)$. Hal ini didukung oleh penelitian Akýn et al. (2009) dan Ribeiro et al. (2015) bahwa kehamilan yang dinantikan dan direncanakan oleh ibu ataupun suami meningkatkan dukungan sosial dari orang terdekat dan keluarga. Ibu memiliki perasaan bahagia akan kehamilan yang telah dinantikannya. Hal ini memberikan efek positif terhadap kualitas hidup postpartum (Rahayuningsih, 2013).

Tabel 11 menunjukkan bahwa responden yang menyusui bayinya rata-rata mendapatkan skor nilai kualitas hidup baik sejumlah 23 
responden (38,33\%) sedangkan responden yang tidak menyusui bayinya hanya sejumlah 2 responden $(3,33)$ yang memperoleh skor nilai kualitas hidup baik. Hasil uji Chi-Square yaitu $p$ value menunjukan hasil 0,002, dapat disimpulkan bahwa $p$-values 0,002 <0,05 artinya Ha diterima yaitu ada pengaruh faktor menyusui terhadap kualitas hidup postpartum. Nilai koefisien kontingensi didapatkan hasil bahwa $\mathrm{C}=0,376$ yaitu kekuatan tingkat hubungan koefisien kontingensi adalah rendah (0,20-0,399).

Penelitian ini didukung oleh (Ribeiro et al., 2015) bahwa ketidakmampuan memberikan ASI kepada bayinya memberikan efek sedih dan frustasi dalam perawatan bayinya. Penelitianya menyimpulkan bahwa menyusui bayi dapat memberikan kontribusi terhadap promosi kesehatan ibu pada masa nifas dan kualitas hidupnya (Prick et al., 2015). Aspek kualitas hidup akan berhubungan dengan masa menyusui dan perawatan bayi (Leight et al., 2011). Ada kebermanfaatan menyusui dan kualitas hidup secara signifikan pada ibu dalam masa postpartum, hal ini dipengaruhi oleh ikatan bounding yang kuat Ketika menyusui bayinya (Zubaran \& Foresti, 2011).

\section{Kesimpulan}

Hasil penelitian dengan hasil uji statistik ChiSquare membuktikan bahwa ada pengaruh faktor demografi meliputi variabel umur, variabel pendidikan, dan variabel penghasilan terhadap kualitas hidup postpartum (Ha diterima, Ho ditolak) dengan $p$-value $0,003<0,05, p$-value $0,001<0,05$, dan $p$-value 0,002<0,05. Faktor obstetrik meliputi paritas, riwayat komplikasi, riwayat abortus, kehamilan diinginkan, dan faktor menyusui mempunyai pengaruh terhadap kualitas hidup postpartum ( $\mathrm{Ha}$ diterima, Ho ditolak) dengan $p$-value $<0,050, p$-value $<003, p$ value $<0,040, p$-value $<0,000, p$-value $<0,017$, dan $p$-value $<0,002$. [].

\section{Daftar Pustaka}

Akýn, B., Ege, E., Koçođlu, D., Demirören, N., \& Yýlmaz, S. (2009). Quality of life and related factors in women, aged 15-49 in the 12month post-partum period in Turkey. Journal of Obstetrics and Gynaecology Research, 35(1), 86-93. https://doi.org/10.1111/j.14470756.2008.00870.x

Alderdice, F., McNeill, J., \& Lynn, F. (2013). A systematic review of systematic reviews of interventions to improve maternal mental health and well-being. Midwifery, 29(4), 389399.

https://doi.org/10.1016/j.midw.2012.05.010

Azale, T., Fekadu, A., Medhin, G., \& Hanlon, C. (2018). Coping strategies of women with postpartum depression symptoms in rural Ethiopia: A cross-sectional community study. BMC Psychiatry, 18(1), 41. https://doi.org/ 10.1186/s12888-018-1624-z

Baghirzada, L., Downey, K. N., \& Macarthur, A. J. (2013). Assessment of quality of life indicators in the postpartum period. International Journal of Obstetric Anesthesia, 22(3), 209216.

https://doi.org/10.1016/j.joa.2013.03.010

Bodhare, T. N., Sethi, P., Bele, S. D., Gayatri, D., \& Vivekanand, A. (2015). Postnatal quality of life, depressive symptoms, and social support among women in Southern India. Women \& Health, 55(3), 353-365. https://doi.org/ 10.1080/03630242.2014.996722 
Bosch, A. A. S. van den, Goossens, M., Bonouvrié, K., Winkens, B., Nijhuis, J. G., Roumen, F. J. M. E., \& Wassen, M. M. L. H. (2018). Maternal quality of life in routine labor epidural analgesia versus labor analgesia on request: results of a randomized trial. Quality of Life Research, 27(8), 2027-2033. https://doi.org/ 10.1007/s11136-018-1838-z

Carlander, A.-K. K., Andolf, E., Edman, G., \& Wiklund, I. (2015). Health-related quality of life five years after birth of the first child. Sexual \& Reproductive Healthcare, 6(2), 101-107. https://doi.org/10.1016/j.srhc.2015.01.005

de Tychey, C., Briançon, S., Lighezzolo, J., Spitz, E., Kabuth, B., de Luigi, V., Messembourg, C., Givan, F., Rosati, A., Thockler, A., \& Vincent, S. (2008). Quality of life, postnatal depression and baby gender. Journal of Clinical Nursing, 17(3), 312-322. https://doi.org/10.1111/ j.1365-2702.2006.01911.x

Fenwick, J., Toohill, J., Gamble, J., Creedy, D. K., Buist, A., Turkstra, E., Sneddon, A., Scuffham, P. A., \& Ryding, E. L. (2015). Effects of a midwife psycho-education intervention to reduce childbirth fear on women's birth outcomes and postpartum psychological wellbeing. BMC Pregnancy and Childbirth, 15(9), 284. https://doi.org/10.1186/s12884-015-0721-y

Lara-Cinisomo, S., Zhu, K., Fei, K., Bu, Y., Weston, A. P., \& Ravat, U. (2018). Traumatic events: Exploring associations with maternal depression, infant bonding, and oxytocin in Latina mothers. BMC Women's Health, 18(1), 1-9. https://doi.org/10.1186/s12905-0180520-5

Leight, K., Fitelson, F., Sarah Kim, \& Baker, A. (2011). Treatment of post-partum depression: a review of clinical, psychological and pharmacological options. International
Journal of Women's Health, 3, 1-14. https://doi.org/10.2147/IJWH.S6938

Miyake, Y., Sasaki, S., Yokoyama, T., Tanaka, K., Ohya, Y., Fukushima, W., Saito, K., Ohfuji, S., Kiyohara, C., Hirota, Y., Osaka Maternal, \& Child Health Study Group. (2006). Risk of postpartum depression in relation to dietary fish and fat intake in Japan: the Osaka Maternal and Child Health Study. Psychological Medicine, 36(12), 1727-1735. https://doi.org/10.1017/S003329170600870 1

Norman, E., Sherburn, M., Osborne, R. H., \& Galea, M. P. (2010). An exercise and education program improves well-being of new mothers: A randomized controlled trial. Physical Therapy, 90(3), 348-355. https://doi.org/10.2522/ptj.20090139

Prick, B. W., Bijlenga, D., Jansen, A. J. G., Boers, K. E., Scherjon, S. A., Koopmans, C. M., van Pampus, M. G., Essink-Bot, M.-L., van Rhenen, D. J., Mol, B. W., \& Duvekot, J. J. (2015). Determinants of health-related quality of life in the postpartum period after obstetric complications. European Journal of Obstetrics \& Gynecology and Reproductive Biology, 185, 88-95. https://doi.org/ 10.1016/j.ejogrb.2014.11.038

Rahayuningsih, F. B. (2013). Hubungan aktivitas ibu nifas dengan kualitas hidup ibu nifas di wilayah Puskesmas Miri Sragen. Prosiding Konferensi Nasional PPNI Jawa Tengah 2013, 37-40.

Ribeiro, S. G., Symon, A. G., Lessa, P. R. A., de Oliveira, M. F., Aquino, P. de S., de Almeida, P. C., \& Pinheiro, A. K. B. (2015). Translation and cultural adaptation of the Mother-Generated Index into Brazilian Portuguese: A postnatal quality of life study. Midwifery, 31(7), 735- 
741.

https://doi.org/10.1016/j.midw.2015.03.009

Rowe, H., Sperlich, M., Cameron, H., \& Seng, J. (2014). A quasi-experimental outcomes analysis of a psychoeducation intervention for pregnant women with abuse-related posttraumatic stress. Journal of Obstetric, Gynecologic \& Neonatal Nursing, 43(3), 282 293. https://doi.org/10.1111/1552-6909. 12312

Top, E. D., \& Karaçam, Z. (2016). Effectiveness of structured education in reduction of postpartum depression ccores: A quasiexperimental study. Archives of Psychiatric Nursing, 30(3), 356-362. https://doi.org/ 10.1016/j.apnu.2015.12.009

Torkan, B., Parsay, S., Lamyian, M., Kazemnejad, A., \& Montazeri, A. (2009). Postnatal quality of life in women after normal vaginal delivery and caesarean section. BMC Pregnancy and
Childbirth, 9(1), 4-10. https://doi.org/ 10.1186/1471-2393-9-4

Webster, J., Nicholas, C., Velacott, C., Cridland, N., \& Fawcett, L. (2011). Quality of life and depression following childbirth: impact of social support. Midwifery, 27(5), 745-749. https://doi.org/10.1016/j.midw.2010.05.014

Zhou, S.-Z., Wang, X.-L., \& Wang, Y. (2009). Design of a questionnaire for evaluating the quality of life of postpartum women (PQOL) in China. Quality of Life Research, 18(4), 497-508. https://doi.org/10.1007/s11136-009-9466-2

Zubaran, C., \& Foresti, K. (2011). Investigating quality of life and depressive symptoms in the postpartum period. Women and Birth, 24(1), 10-16.

https://doi.org/10.1016/j.wombi.2010.05.00 2 